DAI Wanwen, ZHAO Shuming

\title{
The cross-cultural impact on organizational learning: A comparative study between China and the Netherlands
}

\author{
(C) Higher Education Press and Springer-Verlag 2008
}

\begin{abstract}
Based on the theory of cross-cultural management and organizational learning, this paper comparatively analyzes the role of culture differences between China and the Netherlands in organizational learning processes, climate, and capabilities. Three propositions are proposed to help multinational corporations (MNCs) build learning-oriented subsidiaries in China.
\end{abstract}

Keywords organizational learning, cross-culture, comparative study

摘要 基于跨文化分析架构, 就中国和荷兰的社会文化对组织学习过程、组织学习 氛围和组织学习能力的影响进行比较, 提出 3 个有待进一步证实的命题, 以期引起人 们对跨文化组织学习实证研究的关注, 为跨国公司在华子公司打造学习型组织的实 践提供理论基础。

关键词 组织学习, 跨文化, 比较研究

\section{Introduction}

Since the seminal work of Cyert and March (1963), Cangelosi and Dill (1965), and Ariyris and Schon (1978), organizational learning has grown rapidly both in academia and in practice. Much research has been completed on why

Received January 30, 2008

DAI Wanwen $(\bowtie)$

Business School, Nanjing University, Nanjing 210093, China

E-mail: wwdai@nju.edu.cn

ZHAO Shuming

Business School, Nanjing University, Nanjing 210093, China

E-mail: zhaosm@nju.edu.cn 
organizations must learn, how and when they learn (Fiol and Lyles, 1985; Crossan et al., 1995; Lahteenmaki et al., 2001; Dai, 2005b). According to these studies, organizational learning involves psychological processes and behavioral processes (Nonaka and Tadeuchi, 1995; Dixon, 1999; Crossan, 1999). Social cultural differences should be regarded as a key variable that influences organizational learning and the learning result (Dai and Cheng, 2004).

Research on cross-culture shock should pay close attention to organizational learning theories originated from the west to frame business management theory and its application in China (Zhao, 1997). Although much has been written on the cross-cultural factors influencing the processes of building a learning organization, there is little research on the learning organization and organizational learning in the cross-cultural context (Garvin, 1993; Dixon, 1999). In addition, the cognitive perspective, often using a computer model of the individual mind in an organizational setting, ignored the social and cultural aspects of organizational learning (Cook and Yanow, 1993).

Culture can be an invigorating factor of organizational learning as much as an inhibiting one (Schein, 1994). To address how different cultures influence the organizational learning process, organizational learning climate, and organizational capability, in the present study we focus on those determining factors of social culture that are especially relevant in organizational learning in the international cooperation agreements and attempt to fill some of the gaps in the organizational learning research pertaining to China and the Netherlands. In particular, these include an understanding of what cross-cultural factors affect organizational learning and how learning happens in the cross-cultural context. Based on in-depth interviews with middle and high-level managers of three Dutch-based multinational companies (MNCs) like Philips, Akzo Nobel, and DSM in China, we put forward some propositions about the organizational learning under the influence of culture difference between China and the Netherlands. Finally, an empirical study agenda of cross-cultural organizational learning is proposed.

\section{A framework of culture difference between the Netherlands and China}

Social culture is an aggregate product of the processes occurring in human society. It typically consists of such social phenomenon as beliefs, ideas, languages, customs, rules, and family patterns. Expressed in general terms, culture may be understood as a system of widely accepted beliefs combined with a set of self justified assumptions. These beliefs and assumptions are transmitted 
from one generation to the next. Culture is learned and passed on to new members of the group through social interaction and it changes over time.

China and western countries like the Netherlands have shared a history of more than eight hundred years of interaction and mutual influence. In the first part of this period, the Chinese people influenced the western society in many ways. The Dutch, or better perhaps the "Hollanders", were interested in Chinese technical achievements in silk and textile, and other great inventions by Chinese like powder, compass, paper making, and type printing. Later, especially after the $16^{\text {th }}$ century, the influence seemed to go in the opposite direction. Dutch performance in industry set the examples, which proved to be a learning experience for the rest of world, including the Chinese.

In the age of globalization, we should shift our mindset from "onion" way of analyzing culture to "ocean" way of understanding culture to capture the dynamics of national cultures and international cross-cultural management (Fang, 2004). Chinese and the Netherlands are similar in many aspects. Both China and the Netherlands are said to be consensus societies (D'Iribarne, 1989; Fang, 1999, 2003). Consultation, negotiation, persuasion, cooperation and continuous deliberation are the common features of both societies. In both countries conflicts in social relations are expected to be resolved harmoniously. The Chinese are known for Guanxi (relationship) and Buchixiawen (downwards consultation) in their work organizations and the Dutch for their Polder model in politics and industrial relations (Van Iterson, 2000). In both countries, strong social pacts between businesses, labors and government have existed for decades, but they use very different mechanisms for reaching agreement. So the two societies really are consensus societies, but each with its own characters and flavors.

Hofstede's (1980b) landmark study is the main frame of reference for studies that attempt to gauge the impact of differences in national cultures. In the subsequent edition of his book, Hofstede brought together an impressive number of replications and studies in which the indices developed in the original study are used in widely differing research contexts (Hofstede, 2001), including three different research projects, one among subsidiaries of a multinational corporation (IBM) in 64 countries and the other two among students in 10 and 23 countries, respectively. Recently, the cross-cultural academic research has witnessed growing critiques of the Hofstede paradigm and some important advances have been made in developing a dynamic view of culture, such as new culture negotiation through intercultural interactions (e.g., Brannen and Salk, 2000; Li, 1999). The main focus of the current frame of cultural dynamics is more on organizational culture change (e.g., Hatch 1993) and new culture creation in organization and team settings (e.g., Brannen and Salk, 2000; Sackmann and Phillips, 2004) than on national culture change. It is against the above 
background that this study has been conducted. One of the strong points of Hofstede's work is that it defined culture as "the collective programming of the mind which distinguished the members of one category of people from another, the DNA which makes one social group distinct from the other" (Hofstede, 1980a, 1980b), and provides a national cultural framework including five dimensions, namely power distance, individualism-collectivism, uncertainty avoidance, masculinity-femininity, and long versus short-term orientation (Hofstede, 1980a, 1983, 1991, 2001; Hofstede and Bond, 1984, 1988).

\subsection{Power distance}

The dimension of power distance can be defined as the degree of inequality among people which the population of a country considers to be normal - from relatively equal (small power distance) to extremely unequal (large power distance) (Hofstede 1980a, 1991, 2001). China is a country in which people are very unequal in comparison with the other countries in the world (Hofstede, 2001). Within the traditional Chinese society there are clear hierarchical arrangements based on gender, generation, position and age. China should definitely be regarded as a society made up of tight Guanxi, and some Chinese people do not willingly share what they learned with the others in order to keep the personal relative competitive advantage in the group as long as possible. Although the Dutch are aware of rank and status, the economic and political elites in the Netherlands, including members of the Royal Family (Benedict, 1944), should and in fact do deep a low profile in the interaction with others. In general, one can say that Dutch society traditionally is fairly egalitarian. Elites in Netherlands, including those in working environments, should act as "normal" as possible, whereas the less powerful are protected and the general rule is that no one should dominate (Van der, 1996). This culture feature provides an appropriate climate to learn from others and share what they learned with the others.

\subsection{Uncertainty avoidance}

The dimension of uncertainty avoidance is defined as the degree to which people in a country prefer structured over unstructured situations (Hofstede, 2001). In the strong uncertainty avoidance countries, the feeling prevails that "what is different, is dangerous", while in weak uncertainty avoidance societies, on the contrary, the prevailing feeling would rather be that "what is different, is curious" (Hofstede and Soeters, 2002). In countries high on uncertainty avoidance, people tend to show more nervous energy, while in countries that score low, people are more relaxed and easy-going. The Chinese in Hofstede and Bond's studies scored 
quite high on this dimension and the Chinese society seems quite rigid (Hofstede, 2001). People's behavior in China is traditionally quite strictly prescribed, whereas at the same time people behave more nervously than in most other countries. The concept of "face (Mianzi)" plays a notable role in the discourse between people. Besides the USA, the Netherlands is another society seeing itself as a "station" in a worldwide cultural circuit (de Swaan, 1999). On this dimension, it has been said that the Dutch attach high importance to the reputations of the people they deal with, whereas Chinese people prefer to interact with Guanxi. The Chinese are traditionally accustomed to the way they have interacted and are accustomed to learning from the past, while Dutch are apt to learn from the new and rising.

\subsection{Individualism-collectivism}

The dimension of individualism-collectivism describes the degree to which people in a country prefer to act as an individual rather than as a member of a group (Hofstede, 2001). The opposite of individualism is collectivism. In collectivist societies, a child learns to respect the group to which it belongs, and to differentiate between in-group members and out-group members. On this dimension, the Chinese people scored about average and the Dutch scored more individualist than China according to the findings of Hofstede and Bond's research (Hofstede, 1991; Hofstede and Bond, 1984, 1988). One's behavior in Chinese society depends on whether the others belong to his in-group or not: outsides are treated quite differently. In fact, people in individualist societies are friendlier to outsiders than people in collectivist societies. China's traditional extended family structure helps to explain why Chinese culture, on a world scale, is very collectivist. Reliance on and obligations to the family and group are predominant in Chinese society, far more than in western societies (Hampdern-Turner and Trompenaars, 1993) such as the Netherlands. The Dutch people are very focused on their own family and keen to protect privacy even among the members of a family (Benedict, 1944). In China, parents used to design and arrange almost everything including marriage and work life, although this may be less prevalent for single offspring born after the one child policy.

\subsection{Masculinity-femininity}

The dimension of masculinity-femininity is the degree to which values like assertiveness, performance, success and competition, which in nearly all societies are associated with the role of men, prevail over values such as the quality of life, maintaining warm personal relationships, service, care of the weak, and 
solidarity (Hofstede, 2001). Hofstede's study found China score extremely masculine, a little bit lower than Japan, which holds the single most masculine country of the world (Hofstede and Bond, 1988). The Netherlands, on the contrary, occupies the third most feminine score among the sample countries (Hofstede, 1980a). This dimension therefore shows the largest gap between the Netherlands and China. Merely imaging the opposite of these Chinese ways of behavior, one almost gets a reasonably accurate picture of how things happen in the Netherlands. The Dutch people are very much inclined to protect the inept and take care of the poor and the needy. Chinese masculinity is associated with a large role difference between men and women. This does not mean that Chinese woman have no power: In China each man and woman has specific, different roles in life; the power of Chinese women is traditionally exercised inside of family only, and men outside. Traditionally Chinese women had a lower status, "Before married, she should submit themselves to her father; after being married, to her husband, if widowed, to her sons." Although Chinese women are increasingly highly educated and admitted to the labor force after the liberation in 1949, there are still considerable career barriers and learning obstacles for a professional woman.

\subsection{Long-term versus short-term orientation}

The dimension of long-term versus short-term orientation was found in a study among students in 23 countries around the world, using a questionnaire designed by Chinese scholars. Values associated with long-term orientation are thrift and perseverance; values associated with short-term orientation are respect for tradition, fulfilling social obligations, and protecting one's Mianzi(dignity). Hofstede and Bond (1988) found China score an extremely long-term orientation: it was the single most long-term orientation of all countries in the sample. Most of the high scorers are East-Asian countries and regions, like Hong Kong, Taiwan province of China, Japan, and South Korea. The Netherlands produced the most "Eastern" values and scored average of the western countries included. Some Europeans have called the Dutch "the Chinese of Europe" (Hofstede and Soeters, 2002). For example, the Dutch tendency to save has been observed for centuries and is reported in Benedict's 1944 study. She called the Dutch: prudent, economical and never reckless.

Generally as Table 1 shows, the characteristic of social culture in the Netherlands is high individualism, low power distance, the middle level uncertainty avoidance, femininity and short-term orientation while in China it is low individuality, high power distance, high uncertainty avoidance, masculinity and long-term orientation. 
Table 1 Social culture comparison between China and the Netherlands by Hofstede's schedule

\begin{tabular}{lcc}
\hline \multicolumn{1}{c}{ Index of culture difference } & The Netherlands & China \\
\hline Power distance & 38 & 80 \\
Uncertainty avoidance & 53 & 60 \\
Individualism & 80 & 20 \\
Masculinity & 14 & 50 \\
Long-term orientation & 44 & 118 \\
\hline
\end{tabular}

Another relevant cultural dimension is concerned with how individuals view their relationship with nature and mastery versus subjugation (Kluckhohn and Strodtbeck, 1961). Orientation towards nature influences the extent to which individuals believe they can control their own destiny. Mastery culture believes that one should control and master nature. They are likely to seek change in their working and living environment. In these societies, individuals are socialized to display an internal locus of control (Chandler, 1979). They are conditioned to believe that through their own effort, hard work and choice (internal forces) that they can affect personal outcomes and control their destinies. Thus, success or failure is perceived to be caused primarily by internal factors.

In contrast, cultures with a subjugation orientation believe that life's events are predetermined either by God or nature/fate. Individuals tend to display an external locus of control where fate, luck and chance (external forces) play an important role in affecting life's outcomes (Gopalan and Thomson, 2003). These value orientations and assumptions towards nature affect people perceptions about the causes of their performance. In a mastery society, individual and personal factors are considered the primary forces influencing performance whereas, in a subjugated society, performance outcomes are thought to be influenced by external factors.

Using the Kluckhohn value schedule, we compared Dutch values with Chinese values as Table 2 shows.

Table 2 Social culture comparison between China and the Netherlands by the Kluckhohn value schedule

\begin{tabular}{lll}
\hline \multicolumn{1}{c}{ Cultural value orientation } & The Netherlands & \multicolumn{1}{c}{ China } \\
\hline Relationship to the environment & $\begin{array}{l}\text { Mastery } \\
\text { Present-time } \\
\text { oriented } \\
\text { Time orientation }\end{array}$ & Fubjugation \\
Nature of people & $\begin{array}{c}\text { good and evil } \\
\text { Doing-oriented }\end{array}$ & Good \\
Activity orientation & Individualistic & Controlling-oriented \\
Focus of responsibility & Private & Group \\
Conception of space & & Public \\
\hline
\end{tabular}


Relationship with the environment Cultures can be classified according to the relationship with the environment: subjugation to nature, harmony with nature, and mastery over nature. The Netherlands itself is the result of humans controlling the nature and environment. The Dutch always believe they can and should control and change the environment, "God made the world, Dutch made the Netherlands." While in China, the traditional culture was largely associated with the teachings of Kong $\mathrm{Zi}$ (Confucius), written down about $500 \mathrm{BC}$, which asked people to be kind to the environment and follow nature.

Time orientation Culture also differs in terms of the value of time-past, present or future oriented. Dutch people are present-time oriented, which is evident in the Dutch-based company, as people see time as a valued resource and care about the present, while Chinese take long views on time and see time as the only resource can be prodigal.

Nature of people Does a culture perceive people as good, evil, or mixed (a combination of good and evil)? The beginning words of Confucius in China, Sanzi Jing, state that the human's nature is always good, honest, and trusty, and all evil was the result of the environment. While Dutch people's thinking about the nature of people is mixed, it produced the most "Eastern" values of the Western countries. Other Europeans have earlier called the Dutch "the Chinese of Europe".

Activity orientation Activity orientation is how people focus on their activity, doing, controlling or being. Dutch culture is action-oriented; the Dutch are more likely to view work and work-related activities as being crucial to their existence. Chinese culture is control-oriented, striving for a balance of feeling and thought, mind and body. The Chinese credo is work to live and enjoy the moment.

Focus of responsibility What responsibility does one have for the welfare of others? For Dutch, the answer is that one should take care of him or herself, whereas the Chinese emphasis is more on group harmony, unity, and loyalty.

Concept of space This cultural variable is concerned with how one is oriented toward the surrounding space, especially the sense of ownership of space relative to others (Lane et al., 1996). Dutch culture places a strong emphasis on keeping things private. In contrast, Chinese culture favors doing business in public.

\section{Cross-culture impact on organizational learning}

The email messages were sometimes met with unexpectedly long silences from the counterparts in China... Some Chinese employees seem not to know how and what to do once apart from the supervisors.... It was clear that the Chinese local employees and the expatriated managers from the Netherlands look at the processes from different angles and checkpoints... 


\section{By an expatriated high level manager of Akzo Nobel China}

Culture has many functions according to Faure and Sjostedt (1993). Among other things, culture may be an obstacle with regards to interaction and communication. Carrying out operational functions, such as HR performance feedback, across the diverse cultural contexts of MNCs in China can often lead to cross-cultural misunderstandings. The misunderstandings can lead to communication breakdown and lower morale resulting in lower team performance and potentially higher turnover. If this situation is not addressed appropriately, similar scenarios are likely to occur between expatriated managers and local Chinese employees of MNCs, as illustrated by the comments of the above manager. If properly handed, both expatriates and local employees can transfer the knowledge gained in organizational learning processes, which can benefit the entire MNC and enhance the organizational capability of sustainable competitive advantage in Chinese cultural content.

Cultural misunderstanding and cultural conflict are different, and some misunderstanding is inevitable. MNC managers should primarily strive to prevent these understandings from becoming dysfunctional conflict and view these as opportunities for developing learning that can extend throughout the MNC. This can be accomplished through the organizational learning processes, in the process of settling cross-cultural conflict, the two parties perceive cultural similarities between themselves and other forms of interaction like communication may be facilitated.

According to Hofstede's research, social culture differences have significant impact on the organizational management style, value and behavior, configuration and motivation (Hofstede, 1980; Hofstede and Bond, 1988). So the cross-cultural shock impacts the organizational learning psychology, processes, climate, capability, and the results inevitably. The present study attempts to discuss how the social culture differences can possibly influence the organizational learning process, organizational learning climate and capability respectively.

\subsection{Cross-culture impact on the organizational learning processes}

Dai Wanwen (2004, 2005a, 2005b) proposed four related organizational learning sub-processes including intuiting, interpreting, integrating, and institutionalizing occurred over three levels: individual, group and organization. Based on the view of organization ecology, to embody the culture trait inside, this study indicates the organizational learning process in the Netherlands and China with the introversive sensitive model and extroversive rational model respectively, see Table 3. 
Table 3 Comparison of the organizational learning process between the Netherlands and China

\begin{tabular}{llll}
\hline $\begin{array}{l}\text { Organizational } \\
\text { learning level }\end{array}$ & $\begin{array}{c}\text { Organizational } \\
\text { learning processes }\end{array}$ & $\begin{array}{c}\text { Dutch extroversive } \\
\text { rational model }\end{array}$ & $\begin{array}{c}\text { Chinese introversive } \\
\text { sensitive model }\end{array}$ \\
\hline Individual & Intuiting & $\begin{array}{l}\text { Initiative and } \\
\text { directive } \\
\text { All-sided } \\
\text { interaction }\end{array}$ & $\begin{array}{c}\text { Passive, connotative and } \\
\text { indirect }\end{array}$ \\
Group & Interpreting & Participation & From top to bottom \\
Organization & Integrating & Onstitution oriented & $\begin{array}{c}\text { Leadership and guanxi } \\
\text { oriented }\end{array}$ \\
\hline
\end{tabular}

Intuiting is the preconscious recognition of the pattern and/or possibilities inherent in a personal stream of experience (Weick, 1995b). This process can affect the intuitive individual's action, but it only affects the other members when they attempt to interact with that individual (Crossan et al., 1999). In the Netherlands, the dominant mindset of the Dutch is individualism, the individual level of organizational learning is initiative and directive. However, in China, the character of individualism learning is passivity, connotative, and indirect, that is, most Chinese are good at learning and transferring the new knowledge, but the desire to know or learn in China is not as much as in the Dutch culture content.

Whereas intuiting focuses on the subconscious process of developing insights, interpreting begins pick up on the conscious elements of the individual learning process. Through the process of interpreting, individuals develop cognitive maps about the various domains in which they operate (Huff, 1990). Language plays a pivotal role in the development of their cognitive maps and also in enabling individuals to develop a sense of shared understanding. Negotiation between the Chinese and westerners has been on the rise since China's economic reform policy in 1978. Nevertheless, negotiations are frequently unsatisfactory. According to Li (1999), the language and cultural difference are two of the major obstacles to the success of western MNCs in China. Dutch people show high regard to equality and pay much attention to respecting each other. However, Chinese are receptive to the orders and arrangements from their boss or eldership. In some MNCs in China, some local employees "do not know how and what to do, and are just waiting there for the orders from their supervisors" as one Dutch expatriated senior manager said.

Whereas the focus of interpreting is change in the individual's understanding and action, the focus of integrating is coherent, collective action. For coherence to evolve, shared understanding by members of the group is required. It is through the continuing conversation and communications among members of the community and through shared practice (Seely-Brown and Duguid, 1991) that 
shared understanding or collective mind (Weick and Roberts, 1993) develops and mutual adjustment and negotiated action (Simons, 1991) take place. In the Netherlands, the social culture encourages people to share their experience and what they learned from the past through dialog in the group. Dutch people can attach general agreement through working together. Conversely, most Chinese people are not active in participating and communicating, and an agreement generally comes after supervisors' directions. Actually, Chinese people are very active in a familiar environment, which is why Chinese State-owned companies may encourage employees to see the companies as their own family and the colleagues as family members.

The process of institutionalizing distinguishes organizational learning from individual or ad hoc group learning. The underlying assumption is that organizations are more than simply a collection of individuals and groups; organizational learning is different from simply the sum of the learning of all members (Dai, 2005b). Some learning of individuals and groups embedded in the organizational systems, structures, strategy, routines, prescribed practices of the organization, and investments in information systems and infrastructure (Crossan et al., 1999). In China, there is a proverb, "Past experience, if not forgotten, is a guide for the future". Most Chinese people are effective at leaning from past experience. Whereas Chinese people do not like to share what they learned with each other in a group or in an organization, for they always think, "the nature of human being is selfish". Knowledge dispersed and diffused in China always ties to the relationship, leadership, rules and regulations. In the Netherlands, the development of rules and regulations is basically on the public opinion and is quite standardized; people follow the regulations and rules which constrain the behaviors of everyone in the society. The characteristic of Dutch culture encourages people to learn and to share what they learned with the other group members.

National Culture is a factor that exerts its influence in a significant way on the process of organizational learning. As we discussed above, we can propose Proposition 1 as follows:

Proposition 1 Organizational learning processes that occur on individual, group and organizational levels respectively, would be easier to develop in Dutch society which has the characteristics of high individuality, low power distance, femininity and short-term orientation, compared to the organizational learning processes in the Chinese culture context.

3.2 Cross-culture impact on the organizational learning climate and capabilities

Based on Watkins, Marsick and Yang's organizational learning capabilities dimensions (Watkins and Marsick, 1993, 1996a, 1996b, 1997; Marsick and Watkins 1999, 2003; Yang et al., 2004) an empirical study on the Dutch-based 
MNCs in China (Dai, 2004) showed the cultural difference on individualism vs. collectivism between Dutch and Chinese content significantly influenced the organizational learning capabilities to create continuous learning opportunities on the individual level, encourage collaboration and team learning on the team level, and connect the organization to its environment on the organizational level. Uncertainty avoidance significantly influenced all organizational learning capabilities that occurred over three levels: individual, group, and organization. Femininity significantly influenced promote inquiry and dialogue on the individual level, encourage collaboration and team learning on the team level, and establish system to capture and share learning on the organizational level. Furthermore, short-term orientation significantly influenced the capabilities to connect the organization to its environment, establish systems to capture and share learning, and provide strategic leadership for learning on the organizational level. Lastly, power distance insignificantly influenced all organizational learning capabilities (Dai, 2005b). In a subsequent study, Dai and Heijden (2006) identified three dimensions to measure organizational learning climate which includes learning time, learning opportunity, and group learning cooperation. Table 4 below shows the comparative difference of organizational learning climate and learning capability between the Dutch and Chinese culture context.

Table 4 Comparison of organizational learning climate and learning capability between Dutch culture context and Chinese culture context

\begin{tabular}{|c|c|c|c|}
\hline $\begin{array}{l}\text { Organizational } \\
\text { learning }\end{array}$ & Indicators & $\begin{array}{l}\text { Organization in Dutch } \\
\text { cultural context }\end{array}$ & $\begin{array}{l}\text { Organization in } \\
\text { Chinese cultural } \\
\text { context }\end{array}$ \\
\hline \multirow{3}{*}{ Climate } & Time for learning & Abundant & Deficiency \\
\hline & $\begin{array}{l}\text { Opportunity for } \\
\text { learning }\end{array}$ & Equal & Limited equal \\
\hline & Group cooperation & Smooth & Harmonization \\
\hline \multirow{6}{*}{ Capability } & $\begin{array}{l}\text { Create continuous } \\
\text { learning } \\
\text { opportunities }\end{array}$ & Strong & Weak \\
\hline & Communication & Average & Strong \\
\hline & Group cooperation & Less strong & Less strong \\
\hline & $\begin{array}{l}\text { To build collective } \\
\text { vision }\end{array}$ & Strong & Average \\
\hline & $\begin{array}{l}\text { To adapt to its } \\
\text { environment }\end{array}$ & Less strong & Strong \\
\hline & $\begin{array}{l}\text { Strategic leadership } \\
\text { for learning }\end{array}$ & $\begin{array}{c}\text { Thinking analytical, the } \\
\text { average capability }\end{array}$ & $\begin{array}{l}\text { Thinking integrative, } \\
\text { strong capability }\end{array}$ \\
\hline
\end{tabular}

In the Dutch culture content, the organizational structure is flat and even flatter than that in the American context. Dutch people are enthusiastic coordinators and prefer to communicate with others using other's mother language instead of 
Dutch and even quit the Dutch cultural preference. In the Netherlands, most of the Dutch people can speak four or five foreign languages like English, German, French, and Italian; employees have equal opportunity and enough time to learn and share what they have learned with each other; communication inside the organization and group is smooth. Most of the Dutch people are effective at analytical and rational thinking and they can understand organizations with more rationality and subjectivity; they pay more attention to the short-term output and have a strong willingness and introversive motivation to succeed. They have a thorough plan before achieving learning goals and they are good at sharing learning output in the organization (Dai, 2005).

In China, the traditional inside characteristics of Chinese like connotation, self-surrender, and uphold "the best and the most powerful principle to Chinese is peace", Chinese thinking style is apt to integrative. Guanxi and hierarchy are deeply rooted in Chinese social culture. For Chinese local employees, the opportunity to learn is not equal for everyone in an organization or a group, they always learn with their personal time and are self-taught. Employees are loyal to their organizations as well as their family, but the communication inside an organization is blocked because of the informal groups. Most people will dedicate themselves to the organization they belong to although the capability of building collective vision and the process to get the agreement of all members is not so easy. Employees prefer to adapt to the environment and an outline to learn. The fatalism airs in Chinese always evoke a different or equivocal meaning for the organizational learning behaviors that depart from the organizational learning target (Kluckhohn and Strodteck, 1961).

Therefore, we suggest the Propositions 2 and 3 as follows:

Proposition 2 Compared to Chinese local employees, Dutch people enjoy more time and opportunities for learning, while the group collaboration and team learning are almost the same under the Dutch and Chinese culture context.

Proposition 3 In the Dutch culture context, the capabilities of creating learning opportunity and building collective view in organizational learning are stronger than those in the Chinese culture context; Whereas the capabilities of communicating, adapting to the environment and the strategic leadership for learning in Chinese culture context are stronger than those in the Dutch culture context; China and the Netherlands are quite close on the capabilities of encouraging collaboration and team learning.

\section{Conclusion and discussion}

As a key source to gain sustainable competitive advantage, organizational learning has received much attention from researchers. In a recent survey, the 
Netherlands stood out as the world's best country to integrate good deeds with good business, combining altruism with opportunism (Flynn, 2004). Cross-culture management is the key for a MNC and its subsidiaries to survive and develop overseas, and the organizational learning capabilities in the cross-cultural context are key factors for MNCs to enhance and maintain a sustainable competition advantage. The purpose of this paper is to offer three propositions to be tested through future empirical studies in order to analyze the culture impact on organizational learning process, climate and capabilities respectively. Further research is needed to better understand how social culture influences affect four sub-processes of organizational learning and three factors respectively in Dutch-based MNCs in China. This paper summarizes three propositions that compare potential cultural differences between the Netherlands and China, comparing and contrasting the Chinese and Dutch on various dimensions. Results from empirical studies of the propositions would add to our practical understanding of the differences and the potential impact on the success of organizations.

Acknowledgements This work is supported by the National Science Foundation of China (No. 70732002).

\section{References}

Argyris C, Schon D A(1978). Organizational learning: A theory of action perspective. Reading. MA: Addison Wesley

Benedict R(1944). Notice over her gedrag van Nederlanders. In: R. van Ginkel (1997), Notities over Nederlanders; Antropologisches reflecties. Amsterdam/Meppel: Boom, $87-97$

Brannen M Y, Salk J(2000). Partnering across borders. Human Relations. 53(4): 451-487

Cangelosi V E, Dill W R(1965). Organizational learning: Observations toward a theory. Administrative Science Quarterly, 10: 175-203

Chandler C R(1979). Traditionalism in a modern settings: A comparison of Anglo and Mexican-American value orientations. Human Organization, 38(2): 153-159

Cook S D N, Yanow D(1993). Culture and organizational learning. Journal of Management Inquiry, (2): $373-390$

Crossan M, Henry L, Roderice E(1999). An organizational learning framework: From intuition to institution, Academy of Management Review, 24(3): 522-537

Crossan M, Lane H, White R E, Djurfeldt L(1995). Organizational learning: Dimensions for a theory. International Journal of Organizational Analysis, (3): 337-360

Cyert R M, March J G(1963). A Behavioral Theory of the Firm. Englewood Cliffs, NJ: Prentice Hall

D'iribarne $\mathrm{Ph}(1989)$. La logique de l'honneur. Gestin des enterprises et traditions nationals. Paris: Editions de Seuil

Dai Wanwen, Cheng Deqiu(2004). Cross-cultural challenges to Dutch-based MNCs doing 
business in China. Presented on the $5^{\text {th }}$ International Management Conference, Macau, May, 1908-1917

Dai Wanwen, Heijden B(2006). Role of culture in organizational learning climate: Case study on Philips Lighting. Working paper for DBA program dissertation

Dai Wanwen(2004). Role of culture in organizational learning processes: Case of Dutch based MNCs in China. Thesis for Ph. Master in Maastricht School of Management, Public defended on June 22, 2004 in Maastricht, the Netherlands

Dai Wanwen(2005a). A Study of organizational learning process based on the complex system perspective. Proceedings of the No. 3 Organizational Behavior and Talent Development Conference Between Mainland and Taiwan in China, Shenzhen, 138-149

Dai Wanwen(2005b). An empirical study of cross-culture organizational learning capability in Dutch-based MNC in China. Thesis for Ph. D of management in Nanjing University, Public defended on May 28, 2005 in Nanjing, China

De Swaan A(1999). De draagbare de Swaan (original 1985). Amsterdam: Prometheus

Dixon M(1999). The Organizational Learning Cycle: How Can We Learn Collectively? Aldershot: Grower Publishing

Fang T(1999). Chinese Business Negotiating Style. Thousand Oaks: Sage

Fang T(2003). A critique of Hofstede's fifth national culture dimension. International Journal of Cross Cultural Management, 3(3): 347-368

Fang T(2004). "Onion" to "Ocean": Paradox and change in national cultures. Competitive paper presented at the Academy of International Business (AIB) annual meeting, Beijing, June 23-26

Faure G O, Sjostedt G(1993). Culture and negotiation: An introduction. In: G. O. Faure \& J. Z. Robin (Eds.), Culture and Negotiation (1-13). Newbury park: Sage

Fiol C M, Lyles M A(1985). Organizational learning. Academy of Management Review, 10: 803-813

Garvin D(1993). Building a learning organization? Harvard Business Review, 71(4): 78-91

Gopalan S, Thomson N(2003). National cultures, information search behaviors and the attribution process of cross-national managers: A conceptual framework, Teaching Business Ethics, Dordrecht 7(3): 313

Hampden-Turner C, Trompenaars F(1993). The Seven Culture of Capitalism: Value System for Creating Wealth in the US, Japan, Germany, France, Great-Britain, Sweden and the Netherlands. New York: Currency Doubleday

Hatch M J(1993). The dynamics of organizational culture. Academy of Management Review. 18(4): 657-693

Hofstede G, Bond M(1988). The Confucius connection: From cultural roots to economic growth. Organizational Dynamics, 16(4): 5-22

Hofstede G, Soeters J(2002). Consensus societies with their own character: National cultures in Japan and the Netherlands. Comparative Sociology, 1(1): 1-17

Hofstede G(1980a). Culture's Consequences: International Differences in Work-Related Values. Beverly Hills CA: Sage Pubications

Hofstede G(1980b). Motivation, leadership, and organization: Do American theories apply abroad? Organization Dynamics, 3: 14-42

Hofstede G(1983). Japanese work-related values in a global perspective. In: H. Mannari \& H. Befu (eds.), The Challenge of Japan's Internationalization: Organization and Culture. Tokyo/Nishinomiya: Kodansha International/Kwansei Gakuin University, 148-169

Hofstede G(1991). Cultures and Organizations: Software of the Mind. London: Mcgraw-Hill U. K. Japanese translation: Tabunka Sekai. Tokyo: Yuhikaku, 1995 
Hofstede G(2001). Culture's Consequences (Second Edition): Comparing Values, Behaviors, Institutions and Organizations Across Nations. Thousand Oaks CA: Sage

Huff A S(1990). Mapping Strategic Thought. New York: Wiley

Kluckhohn F, Strodteck F L(1961). Variations in Value Orientation. Evanston, IL: Row, Peterson

Lahteenmaki S, Toivonen J, Mattila M(2001). Critical aspects of organizational learning research and proposals for its measurement. British Journal of Management, 12: 113-129

Lane H W, Distefano J I, Maznevski M L(1996). International Management Behavior. Boston: PWS-Kent

Li Xiangling(1999). Chinese-Dutch Business Negotiations, Insights from Discourse, Amsterdam-Atlanta, GA

Marsick V, Watkins K(1999). Facilitating Learning in Organizations: Making Learning Count. Aldershot, UK: Gower

Marsick V, Watkins K(2003). Demonstrating the value of an organization's learning culture: The dimensions of learning organizations questionnaire, Advances in Developing Human Resource, (5): 132-151

Nonaka I, Tadeuchi H(1995). The Knowledge Creating Company: How Japanese Companies Create the Dynamics of Innovation. New York: Oxford University Press

Sackmann S A, Phillips M E(2004). One's Many Cultures: A Multiple Cultures Perspective. In: N. A. Boyacigiller, R. A. Goodman, and M. E. Phillips(eds), Crossing Cultures: Insights from Master Teachers, 38-47. New York: Routledge

Schein E H(1994). Organizational and managerial culture as facilitator or inhibitor of organizational learning, organizational and managerial culture. http://learning.mit.edu/res/wp/1004.html\#one (Accessed 28 February, 1997)

Seely-Brown I, Duguild P(1991). Organizational learning and communities of practice: Toward a unified view of working, learning and innovation. Organizational Science, 2: $40-57$

Simon H A(1991). Bounded rationality and organizational learning. Organization Science, 2: $125-134$

Van Iterson A(2000). Rules of action in Dutch work organizations. The Netherlands Journal of Social Sciences, 36(2): 176-187

Visser J, Hemelrijck A(1997). "A Dutch Miracle”, Job Growth, Welfare and Corporatism in the Netherlands. Amsterdam: Amsterdam University Press

Watkins K, Marsick V(1993). Sculpting the Learning Organization: Lessons in the Art and Science of Systemic. San Francisco: Jossey-Bass

Watkins K, Marsick V(1996a). Adult educators and the challenge of the learning organization. Adult Learning, 7(4): 18-20

Watkins K, Marsick V(1997). Dimensions of the learning organization questionnaire. Warwick RI: Partners for the Learning Organization

Watkins K, Marsick V(1996b). In action: Creating the learning organization. Alexandria, VA: American Society for Training and Development

Weick K E(1995). Sencemaking in organizations. Thousand Oaks, CA: Sage

Weick K, Roberts K(1993). Collective mind and organizational reliability: The case of flight operations in aircraft carrier deck. Administrative Science Quarterly, 38: 357-381

Yang B, Watkins K, Marsick V(2004). The construct of the learning organization: Dimensions, measurement, and validation. Human Resource Development Quarterly, 15 (1): 31-55

Zhao Shuming(1997). The challenge to multi-national company in China: Culture difference and cross-culture management. Management World, (3): 75-80 (in Chinese) 